\title{
BMJ Open Study of seven single-nucleotide polymorphisms identified in East Asians for association with obesity in a Taiwanese population
}

\author{
Wei-Hsin Huang, ${ }^{1,2}$ Lee-Ching Hwang, ${ }^{1,2,3}$ Hsin-Lung Chan, ${ }^{1,2}$ Hsiang-Yu Lin, ${ }^{2,3,4}$ \\ Yung-Hsiang Lin ${ }^{5}$
}

To cite: Huang W-H, Hwang L-C, Chan $\mathrm{H}-\mathrm{L}$, et al. Study of seven singlenucleotide polymorphisms identified in East Asians for association with obesity in a Taiwanese population. BMJ Open 2016;6:e011713. doi:10.1136/bmjopen-2016011713

- Prepublication history for this paper is available online. To view these files please visit the journal online (http://dx.doi.org/10.1136/ bmjopen-2016-011713).

Received 11 March 2016 Revised 8 July 2016 Accepted 19 July 2016

\section{CrossMark}

${ }^{1}$ Department of Family Medicine, Mackay Memorial Hospital, Taipei, Taiwan 2Department of Medicine, Mackay Medical College, Taipei, Taiwan

${ }^{3}$ Mackay Junior College of Medicine, Nursing and Management, Taipei, Taiwan ${ }^{4}$ Department of Pediatrics, Mackay Memorial Hospital, Taipei, Taiwan

${ }^{5}$ Department of Research and Development, TCI Gene INC, Taipei, Taiwan

Correspondence to Dr Wei-Hsin Huang; whh.5881@mmh.org.tw

\section{ABSTRACT}

Objective: This study aimed to examine singlenucleotide polymorphisms (SNPs) of seven previously reported obesity genes in East Asians and to analyse their associations and synergistic effects on obesity in the Taiwanese population.

Design: Cross-sectional study.

Setting: One medical centre in northern Taiwan. Participants: A total of 323 non-obese and 264 obese participants were recruited. The threshold for obesity in this study was a body mass index of $\geq 27 \mathrm{~kg} / \mathrm{m}^{2}$, as defined by the Ministry of Health and Welfare in Taiwan. The study was performed with the approval of the institutional review board of MacKay Memorial Hospital, Taipei, Taiwan (application number 12MMHIS106).

Outcome measures: We analysed the genotype distributions of seven SNPs localising to the PPAR 2, GNB3, SDC3, ADRB2, FTO, PPARY and ESR1 genes in obese and non-obese groups and then paired obesityrelated SNPs to determine if they have synergistic effects on obesity.

Results: Analysis of the genotype distributions in obese and non-obese groups revealed only a significant positive correlation between an SNP in rs2282440-syndecan 3 (SDC3) and obesity in the Taiwanese population $(p=0.006)$. In addition, the $T / T$ genotype of SDC3 was significantly associated with a larger waist and hip circumference, higher body fat percentage and lower high-density lipoprotein cholesterol. Moreover, the combination of the rs2282440-SDC3T/T genotype with the rs1801282peroxisome proliferator-activated receptor-gamma2 gene (PPARy2) G carrier genotype was strongly associated with obesity ( $O R=6.77)$.

Conclusions: We found that the rs2282440-SDC3T/T genotype is associated with obesity in the Taiwanese population. Furthermore, there is a synergistic effect of the high-risk alleles of the SDC3 and PPARY2 genes on the obese phenotype in the Taiwanese population. Trial registration number: 12MMHIS106; Results.

\section{INTRODUCTION}

Obesity is a major worldwide health concern that predisposes individuals to a high risk of
Strengths and limitations of this study

- This study allows comparison of genotype distributions of seven previously reported obesity-related genes in East Asians between obese and non-obese Taiwanese population.

- This is the first report describing the association of obesity with single-nucleotide polymorphisms (SNPs) in rs2282440-SDC3 and the synergistic effect of SNPs in rs2282440-SDC3 and rs1801282PPAR 2 on obesity in Taiwan.

- Cross-sectional study: The body mass index is not constant. Some participants who have been classified within the obese group at the time of study may fall within the non-obese group several months later.

premature mortality, through an increased risk of chronic diseases, including type 2 diabetes mellitus, cardiovascular diseases, metabolic syndrome and cancer. ${ }^{1}$ The proposed cut-off points of body mass index (BMI) for obesity are defined differently by Taiwan and the WHO. The Ministry of Health and Welfare in Taiwan has defined obesity as a BMI of $\geq 27 \mathrm{~kg} / \mathrm{m}^{2}$ and overweight as BMIs of $\geq 24$ and $<27 \mathrm{~kg} / \mathrm{m}^{2}$. According to the results of the National Health and Nutrition Examination Survey conducted in 1993-1996 and 2005-2008, the prevalence of overweight and obese adults among the Taiwanese population increased from $33 \%$ to $44 \% .^{2}$ Among the top 10 leading causes of death in Taiwan, 8 were related to obesity, including cancer, heart disease, cerebrovascular disease, diabetes, chronic respiratory disease, chronic liver disease and cirrhosis, kidney disease and hypertension. ${ }^{2}$ Therefore, obesity is a serious public health issue in Taiwan. Obesity is regarded as a complex multifactorial disease in which genes play a very important role. Genetic variations may predispose individuals to obesity by controlling the balance between energy intake and expenditure. ${ }^{3} 4$ 
Genetic factors in obesity have recently been estimated to account for $40-70 \%$ of population variance. ${ }^{5} 6$ Large-scale genome-wide association studies (GWAS) have identified at least 58 genetic loci that are robustly associated with obesity-related traits. ${ }^{7}$ The association of BMI, waist circumference and body fat with genetic variation were $16-85 \%,{ }^{8-12} 37-81 \%^{13-15}$ and $35-63 \%,{ }^{16-19}$ respectively. Several genetic loci reported in GWAS have recently been studied to contribute to the development of obesity. ${ }^{2021}$ The majority of loci have been discovered through GWAS in populations of European ancestry, but a growing number of studies are now being performed in populations of non-European ancestry. However, there have been relatively limited studies on SNPs in obesity-related genes within the Taiwanese population. $^{22-27}$ We systematically reviewed PubMed-indexed studies for obesity-associated loci identified in East Asians ${ }^{24-31}$ and selected seven SNPs to analyse their association with and synergistic effects on obesity in the Taiwanese population.

\section{PARTICIPANTS AND METHODS}

\section{Study population}

A population-based study was conducted consisting of 323 control (BMI $<27 \mathrm{~kg} / \mathrm{m}^{2}$ ) and 264 study participants (BMI $\geq 27 \mathrm{~kg} / \mathrm{m}^{2}$ ), aged $20-65$ years. The exclusion criteria were (1) pregnancy, (2) cancer, (3) secondary obesity, (4) hereditary disease (such as Prader-Willi syndrome or Bardet-Biedl syndrome) and (5) BMI $<27 \mathrm{~kg} / \mathrm{m}^{2}$ following bariatric surgery or use of pharmacologic weight reduction agents. The study was approved by the institutional review board of MacKay Memorial Hospital, Taipei, Taiwan (application number 12MMHIS106). All patients signed informed consent forms before participating in this study. Height without shoes and body weight in light clothing were measured to the nearest $0.1 \mathrm{~cm}$ and $0.1 \mathrm{~kg}$, respectively. Height was measured using a standard steel strip stadiometer, and weight was determined using a digital electronic scale. BMI was calculated as weight in kilograms divided by height in metres squared $\left(\mathrm{kg} / \mathrm{m}^{2}\right)$. Waist circumference was measured at the midway point between the lower costal margin and the superior iliac crest in a horizontal plane with flexible anthropometric tape. Body fat was measured using a body composition analyser. The systolic and diastolic blood pressures and heart rate were recorded for all participants. Blood pressure was measured to the nearest $2 \mathrm{~mm} \mathrm{Hg}$ using an appropriately sized cuff and a standard mercury sphygmomanometer in a sitting position by trained nurses. Participants took at least a $10 \mathrm{~min}$ rest before the measurement was taken. Blood samples were drawn with minimal trauma from the antecubital vein in the morning after an overnight fast. Biochemical markers, including total cholesterol, triglycerides, low-density lipoprotein cholesterol (LDL-C), highdensity lipoprotein cholesterol (HDL-C), fasting glucose, insulin, homeostatic model assessment-insulin resistance (HOMA-IR) and high-sensitive $\mathrm{C}$ reactive protein
(hs-CRP), were analysed by a biochemical automated analyser (Beckman Coulter, California, USA).

\section{Genotyping}

Buccal swabs were collected from each participant using standard protocols, and DNA was isolated using the Isohelix Buccal DNA isolation kit (Cell Projects, Kent, UK) as per the manufacturer's instructions. DNA was then purified and concentrated using the DNA Clean and Concentrator kit (Zymo Research, Irvine, California, USA). The quality of isolated genomic DNA was checked using the agarose gel electrophoresis and quantified using spectrophotometry.

We systematically reviewed PubMed-indexed articles for previously identified obesity-related genes in East Asians and selected seven SNPs within the PPARy2, GNB3, SDC3, ADRB2, FTO, PPAR and ESR1 genes. ${ }^{24-31}$ All SNP genotyping was performed using the TaqMan SNP Genotyping assay. The primers and probes for the aforementioned SNPs were from the ABI Assay-on-Demand kit (ABI: Applied Biosystems, Foster City, California, USA). Reactions were carried out according to the manufacturer's protocol. The probe fluorescence signal detection was performed using the ABI StepOnePlus Real-Time PCR System.

\section{Statistical analysis}

SPSS (software V.21.0) was used for all statistical analyses. The categorical data were analysed using the $\chi^{2}$ test, and differences for continuous variables were compared using Student's t-test to compare the characteristics of obese and non-obese participants. Genotype frequencies were evaluated for Hardy-Weinberg equilibrium using a $\chi^{2}$ goodness-of-fit test. Analysis of covariance (ANCOVA) was used to compare clinical variable mean values, while adjusting for the covariates of age and gender. ORs and their 95\% CIs were evaluated. Association between SNPs of candidate genes and obesity was tested via logistic regression analysis at the significance level of 5\%. A Bonferroni correction was applied to adjust the significance level of multiple comparisons. The power to detect significant association was calculated by QUANTO software (http://biostats.usc.edu/software).

\section{RESULTS}

A comparison of characteristics between the study participants and control group is shown in table 1. Participants who were obese had significantly higher values for waist circumference, hip circumference, waist-to-hip ratio, body fat percentage, systolic and diastolic blood pressure, triglycerides, LDL-C, fasting glucose, blood insulin, HOMA-IR and hs-CRP than those in the control group. The association of obesity with SNPs in seven genes is shown in table 2. Analysis of the genotype distributions of the SNPs in obese and non-obese groups revealed a significant positive correlation between SNP in rs2282440-SDC3 and obesity in the Taiwanese population 
Table 1 Demographic and clinical characteristics of study participants

\begin{tabular}{|c|c|c|c|c|c|}
\hline \multirow[b]{2}{*}{ Characteristics } & \multicolumn{2}{|c|}{$\begin{array}{l}\text { Control } \\
\left(B M I<27 \mathrm{~kg} / \mathrm{m}^{2}, \mathrm{~N}=323 \text {, }\right. \\
\text { female } \%=74.0)\end{array}$} & \multicolumn{2}{|c|}{$\begin{array}{l}\text { Obese } \\
\left(B M I \geq 27 \mathrm{~kg} / \mathrm{m}^{2}, N=264,\right. \\
\text { female } \%=48.9)\end{array}$} & \multirow[b]{2}{*}{ p Value ${ }^{\star}$} \\
\hline & Mean & SD & Mean & SD & \\
\hline Age (years) & 40.06 & 11.01 & 40.42 & 10.98 & 0.689 \\
\hline Height (cm) & 162.05 & 7.59 & 166.58 & 8.74 & $<0.001$ \\
\hline Weight (kg) & 60.75 & 8.87 & 86.66 & 14.97 & $<0.001$ \\
\hline BMI $\left(\mathrm{kg} / \mathrm{m}^{2}\right)$ & 23.07 & 2.35 & 31.14 & 4.27 & $<0.001$ \\
\hline Waist circumference $(\mathrm{cm})$ & 73.91 & 8.34 & 97.09 & 13.43 & $<0.001$ \\
\hline Hip circumference $(\mathrm{cm})$ & 92.93 & 5.42 & 108.42 & 10.24 & $<0.001$ \\
\hline Waist-to-hip ratio & 0.79 & 0.07 & 0.9 & 0.09 & $<0.001$ \\
\hline Body fat (\%) & 28.86 & 5.89 & 37.27 & 9.3 & $<0.001$ \\
\hline $\mathrm{SBP}(\mathrm{mm} \mathrm{Hg})$ & 118.09 & 13.7 & 131.77 & 17.84 & $<0.001$ \\
\hline $\mathrm{DBP}(\mathrm{mm} \mathrm{Hg})$ & 74.27 & 10.12 & 82.25 & 13.03 & $<0.001$ \\
\hline Heart rate (bpm) & 75.95 & 13.11 & 76.98 & 13.29 & 0.349 \\
\hline Cholesterol (mg/dL) & 193.99 & 37.66 & 199.53 & 37.84 & 0.078 \\
\hline Triglyceride (mg/dL) & 86.24 & 49.01 & 147.38 & 110.86 & $<0.001$ \\
\hline LDL-C (mg/dL) & 114.49 & 33.98 & 123.51 & 32.57 & 0.001 \\
\hline HDL-C (mg/dL) & 61.61 & 15.54 & 48.02 & 12.06 & $<0.001$ \\
\hline Glucose (mg/dL) & 88.78 & 12.41 & 103.2 & 32.26 & $<0.001$ \\
\hline Insulin $(\mu \mathrm{U} / \mathrm{mL})$ & 6.96 & 4.31 & 16.91 & 17.15 & $<0.001$ \\
\hline HOMA-IR & 1.56 & 1.09 & 4.61 & 6.08 & $<0.001$ \\
\hline hs-CRP (mg/dL) & 0.14 & 0.29 & 0.3 & 0.45 & $<0.001$ \\
\hline
\end{tabular}

$(\mathrm{p}=0.006)$. Besides a higher $\mathrm{BMI}$, the $\mathrm{T} / \mathrm{T}$ genotype of $S D C 3$ was also significantly associated with a larger waist and hip circumference, higher body fat percentage and lower HDL-C (table 3). Furthermore, we examined the synergistic effects of rs2282440-SDC3 with SNPs of the other genes on obesity. We performed an OR analysis by comparing the addition of minor or major alleles in the other genes to the $S D C 3 T / \mathrm{T}$ genotype versus their addition to the $S D C 3 \mathrm{C} / \mathrm{C}+\mathrm{C} / \mathrm{T}$ genotypes. We found that there was a synergistic effect of the SNPs in rs2282440-SDC3 and rs1801282-PPARr2 on obesity (table 4). Participants with concomitant rs2282440-SDC3T/T and 1801282rs-PPAR $2 \mathrm{C} / \mathrm{G}$ genotypes had a higher risk of obesity $(\mathrm{OR}=6.77)$, larger waist circumference $(\mathrm{OR}=5.40)$, larger waist-to-hip ratio $(\mathrm{OR}=4.08)$, higher body fat percentage $(\mathrm{OR}=4.65)$ and higher serum triglycerides $(\mathrm{OR}=3.52)$. Finally, statistical power analysis revealed that the present study had $97.01 \%$ power, when using 0.25 as the allele frequency, 0.20 as the baseline disease risk and 2.0 in the effect size among obese and control participants in the complete sample population to detect associations of rs2282440-SDC3 with obesity.

\section{DISCUSSION}

The prevalence of overweight and obese adults is increasing in Taiwan. ${ }^{2}$ Obesity is an important worldwide public health issue, and a large number of potential obesity-associated genetic loci have been reported. To the best of our knowledge, this is the first report describing the association of obesity with an SNP in rs2282440-SDC3 in Taiwan. One study revealed that the Arg16Gly polymorphism of $A D R B 2$ was significantly associated with obesity in Taiwanese female adolescents. ${ }^{26}$ Another study found that three novel SNPs in ESR1 and PPAR resulted in a $>5$-fold risk of severe obesity in the Han Chinese population. $^{29}$ These SNPs (rs1042714-ADRB2, rs712221-ESR1, rs1822825-PPAR $)$ were included in our study; however, no significant differences were found in their genotype distributions between obese participants and non-obese controls. In addition, the rs5443-GNB3 SNP did not exhibit a significant association with obesity in our study but was previously found to be correlated with obesity in the Taiwanese population according to a study by Hsiao et al. ${ }^{24}$ Our study shows that among the seven obesity-related genes previously reported in East Asians, SNP in rs2282440-SDC3 is the only one positively associated with obesity in the Taiwanese population. $S D C 3$ is expressed in the hypothalamic feeding centres and is involved in the regulation of energy balance. Furthermore, syndecan-3 protein expression in the hypothalamus is upregulated in response to food deprivation. SDC3-null mice responded to food deprivation with reduced reflex hyperphagia. ${ }^{32}$ One study demonstrated that SDC3-null mice have reduced adipose content compared with wild-type mice. When given a high-fat diet, SDC3-null male and female mice exhibited a partial 
Table 2 Association of obesity with SNPs in seven genes

\begin{tabular}{|c|c|c|c|c|c|c|c|c|c|}
\hline \multirow[b]{2}{*}{ Gene (SNP) } & \multirow[b]{2}{*}{ Genotype } & \multicolumn{2}{|c|}{ Control } & \multicolumn{3}{|l|}{ Obese } & \multicolumn{3}{|c|}{ Adjusted model* } \\
\hline & & Count & Per cent & Count & Per cent & p Valuet & OR & $95 \% \mathrm{Cl}$ & p Value \\
\hline \multirow{4}{*}{ PPAR 2 (rs1801282) } & $\mathrm{C} / \mathrm{C}$ & 263 & 81.4 & 224 & 84.8 & 0.024 & Reference & & \\
\hline & $\mathrm{C} / \mathrm{G}$ & 60 & 18.6 & 40 & 15.2 & & 0.845 & 0.537 to 1.329 & 0.466 \\
\hline & $\mathrm{G} / \mathrm{G}$ & 0 & 0.0 & 0 & 0.0 & & NA & NA & NA \\
\hline & G carrier & 60 & 18.6 & 40 & 15.2 & & 0.845 & 0.537 to 1.329 & 0.466 \\
\hline \multirow[t]{4}{*}{ GNB3 (rs5443) } & $\mathrm{C} / \mathrm{C}$ & 59 & 18.2 & 48 & 18.2 & 0.393 & Reference & & \\
\hline & $\mathrm{C} / \mathrm{T}$ & 162 & 50.2 & 137 & 51.9 & & 0.950 & 0.597 to 1.510 & 0.827 \\
\hline & $\mathrm{T} / \mathrm{T}$ & 102 & 31.6 & 79 & 29.9 & & 0.901 & 0.547 to 1.486 & 0.684 \\
\hline & $\mathrm{T}$ carrier & 264 & 81.8 & 216 & 81.8 & & 0.931 & 0.600 to 1.445 & 0.749 \\
\hline \multirow[t]{4}{*}{ SDC3 (rs2282440) } & $\mathrm{C} / \mathrm{C}$ & 78 & 24.1 & 51 & 19.3 & 0.074 & Reference & & \\
\hline & $\mathrm{C} / \mathrm{T}$ & 184 & 57.0 & 131 & 49.6 & & 1.109 & 0.720 to 1.711 & 0.638 \\
\hline & $\mathrm{T} / \mathrm{T}$ & 61 & 18.9 & 82 & 31.1 & & 2.016 & 1.221 to 3.327 & 0.006 \\
\hline & $\mathrm{T}$ carrier & 245 & 75.9 & 213 & 80.7 & & 1.339 & 0.887 to 2.023 & 0.165 \\
\hline \multirow[t]{4}{*}{ ADRB2 (rs1042714) } & $\mathrm{C} / \mathrm{C}$ & 247 & 76.5 & 213 & 80.7 & 0.923 & Reference & & \\
\hline & $\mathrm{C} / \mathrm{G}$ & 73 & 22.6 & 46 & 17.4 & & 0.737 & 0.481 to 1.129 & 0.161 \\
\hline & $\mathrm{G} / \mathrm{G}$ & 3 & 0.9 & 5 & 1.9 & & 1.758 & 0.397 to 7.781 & 0.457 \\
\hline & G carrier & 76 & 23.5 & 51 & 19.3 & & 0.780 & 0.516 to 1.180 & 0.239 \\
\hline \multirow[t]{4}{*}{ FTO (rs6499640) } & $\mathrm{G} / \mathrm{G}$ & 206 & 63.8 & 181 & 68.6 & 0.698 & Reference & & \\
\hline & $\mathrm{G} / \mathrm{A}$ & 104 & 32.2 & 77 & 29.2 & & 0.852 & 0.589 to 1.223 & 0.396 \\
\hline & $\mathrm{A} / \mathrm{A}$ & 13 & 4.0 & 6 & 2.3 & & 0.364 & 0.130 to 1.020 & 0.055 \\
\hline & A carrier & 117 & 36.2 & 83 & 31.5 & & 0.788 & 0.551 to 1.128 & 0.193 \\
\hline \multirow{4}{*}{ PPAR (rs1822825) } & $\mathrm{G} / \mathrm{G}$ & 113 & 35.0 & 89 & 33.7 & 0.037 & Reference & & \\
\hline & $\mathrm{G} / \mathrm{A}$ & 163 & 50.5 & 142 & 53.8 & & 1.140 & 0.787 to 1.651 & 0.489 \\
\hline & $\mathrm{A} / \mathrm{A}$ & 47 & 14.6 & 33 & 12.5 & & 0.837 & 0.485 to 1.443 & 0.522 \\
\hline & A carrier & 210 & 65.1 & 175 & 66.3 & & 1.069 & 0.750 to 1.525 & 0.711 \\
\hline \multirow[t]{4}{*}{ ESR1 (rs712221) } & $\mathrm{A} / \mathrm{A}$ & 105 & 32.5 & 88 & 33.3 & 0.688 & Reference & & \\
\hline & $A / T$ & 158 & 48.9 & 125 & 47.3 & & 0.850 & 0.580 to 1.247 & 0.406 \\
\hline & $T / T$ & 60 & 18.6 & 51 & 19.3 & & 0.892 & 0.548 to 1.452 & 0.645 \\
\hline & $\mathrm{T}$ carrier & 218 & 67.5 & 176 & 66.6 & & 0.862 & 0.601 to 1.236 & 0.418 \\
\hline
\end{tabular}

Table 3 Comparison of clinical variables of SNPs in rs2282440-SDC3

\begin{tabular}{|c|c|c|c|c|c|}
\hline \multirow{3}{*}{$\begin{array}{l}\text { Gene (SNP) } \\
\text { Genotype } \\
\text { Dependent variable }\end{array}$} & \multicolumn{4}{|c|}{ SDC3 (rs2282440) } & \multirow[b]{3}{*}{ p Value } \\
\hline & \multicolumn{2}{|c|}{$\mathrm{C} / \mathrm{C}$ and $\mathrm{C} / \mathrm{T}(\mathrm{N}=444)$} & \multicolumn{2}{|c|}{$T / T(N=143)$} & \\
\hline & Mean & SE & Mean & SE & \\
\hline BMI $\left(\mathrm{kg} / \mathrm{m}^{2}\right)$ & 26.39 & 0.24 & 27.65 & 0.42 & 0.010 \\
\hline Waist circumference $(\mathrm{cm})$ & 83.46 & 0.68 & 87.05 & 1.21 & 0.010 \\
\hline Hip circumference $(\mathrm{cm})$ & 99.24 & 0.51 & 101.90 & 0.90 & 0.009 \\
\hline Waist-to-hip ratio & 0.84 & 0.00 & 0.85 & 0.01 & NS \\
\hline Body fat (\%) & 32.19 & 0.38 & 34.04 & 0.68 & 0.018 \\
\hline $\mathrm{SBP}(\mathrm{mm} \mathrm{Hg})$ & 123.70 & 0.77 & 125.90 & 1.35 & NS \\
\hline DBP (mm Hg) & 77.59 & 0.55 & 78.67 & 0.98 & NS \\
\hline Heart rate $(\mathrm{bpm})$ & 76.28 & 0.62 & 76.82 & 1.09 & NS \\
\hline Cholesterol (mg/dL) & 196.50 & 1.74 & 196.30 & 3.07 & NS \\
\hline Triglyceride (mg/dL) & 110.00 & 4.03 & 125.40 & 7.10 & 0.059 \\
\hline LDL-C (mg/dL) & 118.50 & 1.57 & 118.60 & 2.78 & NS \\
\hline HDL-C (mg/dL) & 56.17 & 0.66 & 53.41 & 1.17 & 0.040 \\
\hline Glucose (mg/dL) & 94.64 & 1.12 & 97.20 & 1.97 & NS \\
\hline Insulin $(\mu \mathrm{U} / \mathrm{mL})$ & 11.09 & 0.61 & 12.52 & 1.07 & NS \\
\hline HOMA-IR & 2.83 & 0.21 & 3.24 & 0.37 & NS \\
\hline hs-CRP (mg/dL) & 0.21 & 0.02 & 0.22 & 0.03 & NS \\
\hline
\end{tabular}


Table 4 Combined effects of SNPs in rs2282440-SDC3 and rs1801282-PPAR $\gamma 2$

\begin{tabular}{|c|c|c|c|c|c|c|}
\hline Characteristics & SDC3 rs2282440 & PPAR 2 1801282rs & OR & Upper $95 \% \mathrm{Cl}$ & Lower $95 \% \mathrm{Cl}$ & p Value* \\
\hline \multirow[t]{3}{*}{ BMI } & C carrier & $\mathrm{C} / \mathrm{C}$ & 1.00 & & & \\
\hline & $\mathrm{T} / \mathrm{T}$ & $\mathrm{C} / \mathrm{C}$ & 1.6 & 1.07 & 2.45 & 0.022 \\
\hline & $\mathrm{T} / \mathrm{T}$ & G carrier & 6.77 & 1.87 & 24.54 & 0.004 \\
\hline \multirow[t]{3}{*}{ Waist circumference } & C carrier & $\mathrm{C} / \mathrm{C}$ & 1.00 & & & \\
\hline & $\mathrm{T} / \mathrm{T}$ & $\mathrm{C} / \mathrm{C}$ & 1.50 & 1.00 & 2.25 & 0.051 \\
\hline & $\mathrm{T} / \mathrm{T}$ & G carrier & 5.40 & 1.51 & 19.31 & 0.010 \\
\hline \multirow{3}{*}{ Waist-to-hip ratio } & C carrier & $\mathrm{C} / \mathrm{C}$ & 1.00 & & & \\
\hline & $\mathrm{T} / \mathrm{T}$ & $\mathrm{C} / \mathrm{C}$ & 1.56 & 1.00 & 2.45 & 0.049 \\
\hline & $\mathrm{T} / \mathrm{T}$ & G carrier & 4.08 & 1.49 & 11.18 & 0.006 \\
\hline \multirow[t]{3}{*}{ Body fat (\%) } & C carrier & $\mathrm{C} / \mathrm{C}$ & 1.00 & & & \\
\hline & $\mathrm{T} / \mathrm{T}$ & $\mathrm{C} / \mathrm{C}$ & 1.45 & 0.97 & 2.17 & 0.069 \\
\hline & $\mathrm{T} / \mathrm{T}$ & G carrier & 4.65 & 1.48 & 14.59 & 0.009 \\
\hline \multirow[t]{3}{*}{ Triglycerides } & C carrier & $\mathrm{C} / \mathrm{C}$ & 1.00 & & & \\
\hline & $\mathrm{T} / \mathrm{T}$ & $\mathrm{C} / \mathrm{C}$ & 1.51 & 0.92 & 2.47 & 0.107 \\
\hline & $\mathrm{T} / \mathrm{T}$ & G carrier & 3.52 & 1.25 & 9.93 & 0.017 \\
\hline
\end{tabular}

resistance to obesity due to reduced food intake in males and increased energy expenditure in females, relative to that of wild-type mice. ${ }^{33}$ A strongly positive association of obesity with SNP in rs2282440-SDC3 was also found in the Korean population. ${ }^{30}$ Besides a higher BMI, our study also shows that an SNP in rs2282440-SDC3 was significantly associated with larger waist and hip circumference, higher body fat percentage and lower HDL-C. Although evidence of $S D C 3$ in the regulation of energy balance has been published, few genetic studies concerning the association between SDC3 and obesity have been reported. Marked ethnic difference is present in studies, ${ }^{30} 34$ and this is the first report describing the association of $S D C 3$ and obesity in the Taiwanese population.

After we identified $S D C 3$ as an obesity-related gene in our population, we attempted to analyse whether it has synergistic effects with other genes on obesity. We found that the combination of SNPs in rs2282440-SDC3 and rs1801282-PPAR 2 resulted in an increased risk of obesity (OR=6.77; 95\% CI 1.87 to 24.54 ). In our study, we identified no participants with the rs1801282-PPARY 2 $\mathrm{G} / \mathrm{G}$ genotype (Hardy-Weinberg equilibrium $\mathrm{p}$ value was $0.024)$. The rarity of the rs $1801282-P P A R \gamma 2 \mathrm{G} / \mathrm{G}$ genotype in the Taiwanese population has previously been noted in two other studies. ${ }^{22} 27$ There were only 3 out of 663 participants with the rs1801282-PPAR $2 \mathrm{G} / \mathrm{G}$ genotype in Hsiao's study and 0 out of 596 participants in Lei's study. PPAR is a nuclear receptor that controls the transcription of genes involved in free fatty acid uptake and lipogenesis. PPAR 2 is an isoform that is abundantly expressed in adipose tissue, and has been shown to play an important role in the regulation of insulin sensitivity and adipose tissue metabolism. ${ }^{35} \mathrm{SNP}$ rs1801282 $(\mathrm{C} \rightarrow \mathrm{G})$ results in a Pro12Ala substitution in PPAR 2. A large number of studies assessing the association between this PPARY 2 polymorphism and BMI have been reported with controversial results. ${ }^{36}$ One meta-analysis revealed a higher BMI with an overall estimation of $+0.065 \mathrm{~kg} / \mathrm{m}^{2}$
(95\% CI 0.026 to $0.103, \mathrm{p}=0.001$ ) for homozygous and heterozygous carriers of the Ala allele of the PPAR 2 gene in comparison to non-carriers. ${ }^{36}$ Another study suggested that in the Taiwanese population, the Pro12Ala PPAR 2 variant may contribute to fat accumulation and a higher BMI independent of type 2 diabetes mellitus. Additionally, carriers of the Ala12 allele have a 2.9 times (95\% CI 1.5 to 5.5) higher chance of having a BMI of at least $25 \mathrm{~kg} / \mathrm{m}^{2}{ }^{27}$ Our study shows the distribution of polymorphisms in rs1801282-PPAR 2 in non-obese and obese participants was not significantly different. However, the combination of homozygous T/ $\mathrm{T}$ genotype in rs2282440-SDC3 and heterozygous $\mathrm{C} / \mathrm{G}$ genotype in rs1801282-PPAR 2 resulted in an increased risk for obesity and obesity-related metabolic traits, such as waist circumference, waist-to-hip ratio, body fat percentage and higher serum triglycerides. Owing to previously described roles of SDC3 in the feeding response and PPARY 2 in adipocyte differentiation and insulin sensitivity, we postulate that the reason for the synergistic effect of SNPs in these genes on obesity may be the result of hyperphagia with increased fat accumulation. As this is the first report of synergism between SNPs in SDC3 and PPARY2, the true mechanism is still unclear and will require further studies for confirmation.

\section{CONCLUSION}

Although a large number of SNPs in obesity-related genes had previously been reported, there had been relatively a few studies in the Taiwanese population. We found that SNPs in rs2282440-SDC3 were associated with obesity in the Taiwanese population. Furthermore, there was a synergistic effect of the high-risk alleles in the $S D C 3$ and PPAR 2 genes on the obese phenotype in the Taiwanese population. Use of these SNPs as a potential biomarker for obesity risk in the Taiwanese population 
could allow for potential early lifestyle modifications in those individuals with heritable risks.

Acknowledgements The authors thank Ms Fang-Ju Sun for her professional assistance in biostatistics and Dr Betty C.C. Chang and Dr Victor T.G. Lin for editorial assistance.

Contributors $\mathrm{W}-\mathrm{HH}, \mathrm{L}-\mathrm{CH}, \mathrm{H}-\mathrm{LC}$ and $\mathrm{Y}-\mathrm{HL}$ participated in the design of the study and interpretation of the data. $\mathrm{W}-\mathrm{HH}, \mathrm{L}-\mathrm{CH}$ and $\mathrm{H}-\mathrm{YL}$ helped to draft the manuscript. L-CH and Y-HL performed acquisition and statistical analyses. $\mathrm{W}-\mathrm{HH}, \mathrm{L}-\mathrm{CH}$ and $\mathrm{H}-\mathrm{LC}$ were responsible for participant screening. W-HH and $\mathrm{H}-\mathrm{YL}$ contributed in revising drafts of the manuscript, and all authors had the approval of the final manuscript.

Funding This study was supported by the TCI Gene.

Competing interests None declared.

Patient consent Obtained.

Ethics approval MacKay Memorial Hospital.

Provenance and peer review Not commissioned; externally peer reviewed.

Data sharing statement No additional data are available.

Open Access This is an Open Access article distributed in accordance with the Creative Commons Attribution Non Commercial (CC BY-NC 4.0) license, which permits others to distribute, remix, adapt, build upon this work noncommercially, and license their derivative works on different terms, provided the original work is properly cited and the use is non-commercial. See: http:// creativecommons.org/licenses/by-nc/4.0/

\section{REFERENCES}

1. Razquin C, Marti A, Martinez JA. Evidences on three relevant obesogenes: MC4R, FTO and PPAR $\gamma$. Approaches for personalized nutrition. Mol Nutr Food Res 2011;55:136-49.

2. Taiwan Public Health Report 2013. Health Promotion Administration Ministry of Health and Welfare. http://www.hpa.gov.tw/BHPNet/ English/ClassShow.aspx?No=201401170001

3. Swithers SE, Martin AA, Davidson TL. High-intensity sweeteners and energy balance. Physiol Behav 2010;100:55-62.

4. Drewnowski A. Obesity, diets, and social inequalities. Nutr Rev 2009;67(Suppl 1):S36-9.

5. Chung WK, Leibel RL. Considerations regarding the genetics of obesity. Obesity (Silver Spring) 2008;16(Suppl 3):S33-9.

6. Wardle J, Carnell S, Haworth CM, et al. Evidence for a strong genetic influence on childhood adiposity despite the force of the obesogenic environment. Am J Clin Nutr 2008;87:398-404.

7. Lu Y, Loos RJ. Obesity genomics: assessing the transferability of susceptibility loci across diverse populations. Genome Med 2013;5:55.

8. Platte P, Papanicolaou GJ, Johnston J, et al. A study of linkage and association of body mass index in the Old Order Amish. Am J Med Genet C Semin Med Genet 2003;121C:71-80.

9. Adeyemo A, Luke A, Cooper R, et al. A genome-wide scan for body mass index among Nigerian families. Obes Res 2003;11:266-73.

10. McQueen MB, Bertram L, Rimm EB, et al. A QTL genome scan of the metabolic syndrome and its component traits. BMC Genet 2003;4(Suppl 1):S96.

11. Allison DB, Kaprio J, Korkeila M, et al. The heritability of body mass index among an international sample of monozygotic twins reared apart. Int J Obes Relat Metab Disord 1996;20:501-6.

12. Pietiläinen $\mathrm{KH}$, Kaprio J, Rissanen $\mathrm{A}$, et al. Distribution and heritability of BMI in Finnish adolescents aged 16y and 17y: a study of 4884 twins and 2509 singletons. Int J Obes Relat Metab Disord 1999;23:107-15.

13. Hsueh WC, Mitchell BD, Aburomia R, et al. Diabetes in the Old Order Amish: characterization and heritability analysis of the Amish Family Diabetes Study. Diabetes Care 2000;23:595-601.

14. Hunt KJ, Duggirala R, Göring $\mathrm{HH}$, et al. Genetic basis of variation in carotid artery plaque in the San Antonio Family Heart Study. Stroke 2002;33:2775-80.
15. Sakul H, Pratley R, Cardon L, et al. Familiarity of physical and metabolic characteristics that predict the development of non-insulin-dependent diabetes mellitus in Pima Indians. Am J Hum Genet 1997;60:651-6.

16. Wu DM, Hong Y, Sun CA, et al. Familial resemblance of adiposity-related parameters: results from a health check-up population in Taiwan. Eur J Epidemiol 2003:18:221-6.

17. Schousboe K, Visscher PM, Erbas B, et al. Twin study of genetic and environmental influences on adult body size, shape, and composition. Int J Obes 2004;28:39-48.

18. Rice T, Daw EW, Gagnon J, et al. Familial resemblance for body composition measures: the HERITAGE Family Study. Obes Res 1997;5:557-62

19. Luke A, Guo X, Adeyemo AA, et al. Heritability of obesity-related traits among Nigerians, Jamaicans and US black people. Int J Obes 2001;25:1034-41

20. Locke AE, Kahali B, Berndt SI, et al. Genetic studies of body mass index yield new insights for obesity biology. Nature 2015;518:197-206.

21. Wen W, Cho YS, Zheng W, et al. Meta-analysis identifies common variants associated with body mass index in East Asians. Nat Genet 2012;44:307-11.

22. Hsiao TJ, Lin E. The Pro12Ala polymorphism in the peroxisome proliferator-activated receptor gamma (PPARG) gene in relation to obesity and metabolic phenotypes in a Taiwanese population. Endocrine 2015;48:786-93.

23. Hsiao TJ, Hwang $\mathrm{Y}$, Chang HM, et al. Association of the rs6235 variant in the proprotein convertase subtilisin/kexin type 1 (PCSK1) gene with obesity and related traits in a Taiwanese population. Gene 2014;533:32-7.

24. Hsiao TJ, Hwang Y, Liu CH, et al. Association of the C825T polymorphism in the GNB3 gene with obesity and metabolic phenotypes in a Taiwanese population. Genes Nutr 2013;8:137-44.

25. Hsiao TJ, Lin E. Evaluation of the glutamine 27 glutamic acid polymorphism in the adrenoceptor $\beta 2$ surface gene on obesity and metabolic phenotypes in Taiwan. $J$ Investig Med 2014;62:310-15.

26. Chou YC, Tsai CN, Lee YS, et al. Association of adrenergic receptor gene polymorphisms with adolescent obesity in Taiwan. Pediatr Int 2012;54:111-16.

27. Lei HH, Chen MH, Yang WS, et al. Peroxisome proliferator-activated receptor gamma 2 Pro12Ala gene variant is strongly associated with larger body mass in the Taiwanese. Metabolism 2000;49:1267-70

28. Wang $X$, Liu J, Ouyang $Y$, et al. The association between the Pro12Ala variant in the PPAR 2 gene and Type 2 diabetes mellitus and obesity in a Chinese population. PLOS One 2013;8:e71985.

29. Chen $\mathrm{HH}$, Lee WJ, Fann CS, et al. Severe obesity is associated with novel single nucleotide polymorphisms of the ESR1 and PPARgamma locus in Han Chinese. Am J Clin Nutr 2009;90:255-62.

30. Ha E, Kim MJ, Choi BK, et al. Positive association of obesity with single nucleotide polymorphisms of syndecan 3 in the Korean population. J Clin Endocrinol Metab 2006;91:5095-9.

31. Wu L, Xi B, Zhang M, et al. Associations of six single nucleotide polymorphisms in obesity-related genes with BMI and risk of obesity in Chinese children. Diabetes. 2010;59:3085-9.

32. Reizes $O$, Lincecum J, Wang Z, et al. Transgenic expression of syndecan-1 uncovers a physiological control of feeding behavior by syndecan-3. Cell 2001;106:105-16.

33. Strader AD, Reizes $O$, Woods SC, et al. Mice lacking the syndecan-3 gene are resistant to diet-induced obesity. J Clin Invest 2004;114:1354-60.

34. Schüring AN, Lutz F, Tüttelmann F, et al. Role of syndecan-3 polymorphisms in obesity and female hyperandrogenism. $J \mathrm{Mol} M e d$ 2009;87:1241-50.

35. Yang J, Gong H, Liu W, et al. The association of Pro12Ala polymorphism in the peroxisome proliferator-activated receptor-gamma2 gene with the metabolic characteristics in Chinese women with polycystic ovary syndrome. Int J Clin Exp Pathol 2013;6:1894-902

36. Galbete C, Toledo E, Martínez-González MA, et al. Pro12Ala variant of the PPARG2 gene increases body mass index: an updated meta-analysis encompassing 49,092 subjects. Obesity (Silver Spring) 2013;21:1486-95. 